\title{
Transnasal Removal of Ectopic Supernumerary Tooth from Cleft Patient \\ Cassinsoort
}

Ivo Cavalcante Pita Neto ${ }^{1,2}$, Jéferson Martins Pereira Lucena Franco ${ }^{2}$, Romildo José de Siqueira Bringel², Milana Drummond Ramos Santana1, Hermes Melo Teixeira Batista1,3, Pablo Pita ${ }^{3}$, Eduardo Costa Studart Soares ${ }^{4}$, Luiz Carlos de Abreu ${ }^{1}$, Luciano Miller Reis Rodrigues ${ }^{1}$

\section{Abstract}

Background: The ectopic teeth can be permanent, deciduous or supernumerary and they are changes caused by the morphogenesis and growth of tissue outside their common positions. The ectopic inclusions occur in about $1 \%$ of the population. They can occur due to bad position of tooth germs, development disorder such as cleft palate, because of aberrant patterns of eruption, lack of space in the dental arch and tooth dislocation due to trauma or a pathological injury.

Case Report: This article had as its main objective to present a clinical case of ectopic supernumerary tooth in the nasal cavity proceeding with its surgical removal from a cleft patient who mainly complained of respiratory obstruction.

Conclusion: The importance of a correct diagnosis and suitable treatment through dental extraction through transnasal access was noted, as well as a simultaneous correction of the oralnasal fistula.

\section{Introduction}

Supernumerary teeth are a type of abnormality which is characterized by the presence of tooth considered addition to the normal number of a dental arch. They can erupt normally, remain impacted, appear themselves reversed or even take an ectopic position. They can occur in an isolated or multiple way, unilaterally or bilaterally, in the maxilla or mandible or both arches [ReIs, et al., 2006].

The ectopic teeth are defects caused by the morphogenesis and growth of tissue outside their common positions. The ectopic inclu- 
sions occur in approximately $1 \%$ of the population [SiLva, et al., 2012; GuPTA, et al., 2001].

Regarding its etiology, it can occur due to bad position of tooth germs, development disorder such as cleft palate, because of aberrant patterns of eruption, lack of space in the dental arch and tooth dislocation due to trauma or a pathological injury [Silva, et al., 2012; ERKMEN, et al., 1998].

The ectopic teeth can be permanent, deciduous or supernumerary [ERKMEN, et al., 1998]. The majority of the cases of ectopic teeth are asymptomatic and they are usually found during a clinical investigation or radiography of routine [I-HUNG LIN, et al., 2004; ERKMEN, et al., 1998].

Patients with orofacial fissures, present themselves during the development of the jaws with large possibilities of morphometric deficit, transverse and anteroposterior atresia, causing malocclusion and maintenance of dental inclusions. There is a tendency of eruption of the teeth through the maxillary fissures hindering the dental treatment including dental extractions, the orthodontic manipulation, and the aesthetic performance for the nasal region and the middle third of the face [FERrelRA, et al., 2004; ReIs, et al., 2006].

This article had as its main objective to present a clinical case of ectopic supernumerary tooth in the nasal cavity proceeding with its surgical removal. Emphasizing the importance of its correct diagnosis and a suitable treatment.

\section{Case Report}

Patient J.A.S, black, 11 years old, female, attended the Surgery and the Oral and Maxillofacial Traumatology Service of the Hospital Regional do Cariri (HRC) in Juazeiro do Norte, Ceará, reporting nasal obstruction with painful clinical condition of the right nostril region, with constant trauma and fetid odor. On clinical examination, this patient with a scar of correction of cleft lip and palate was observed. There was the presence of supernumerary tooth in the right nostril inside the nasal cavity floors, in in- verted position and obliterating space of the upper airway (Figure 1).

After clinical and radiographic examination, the presence of inverted supernumerary tooth was confirmed in the nasal cavity, presence of tooth 11 bad positioned and oronasal communication. (Figures $\mathbf{2}$ and $\mathbf{3}$ )

Figure 1: Facial aspect demonstrating supernumerary tooth in the right nostril.
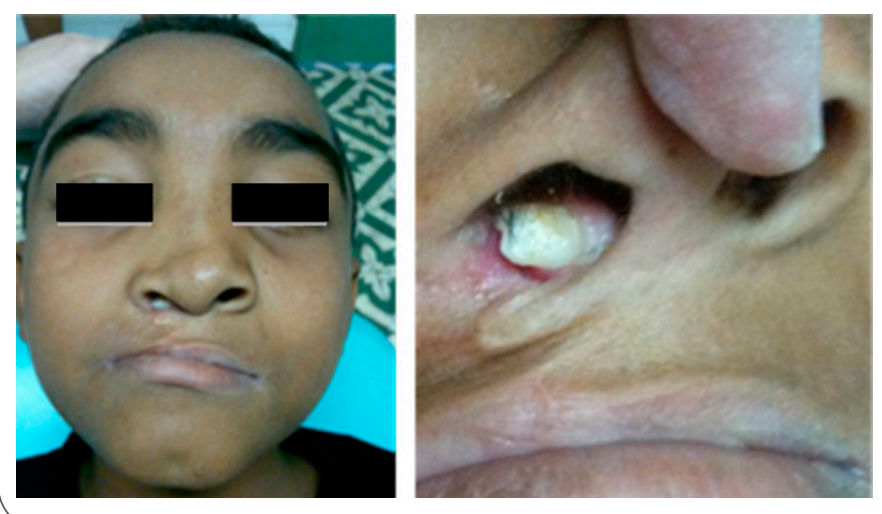

Figure 2: Panoramic radiography revealing the presence of a nasopalatine fissure and poorly positioned teeth with supernumerary on display in the nasal cavity.

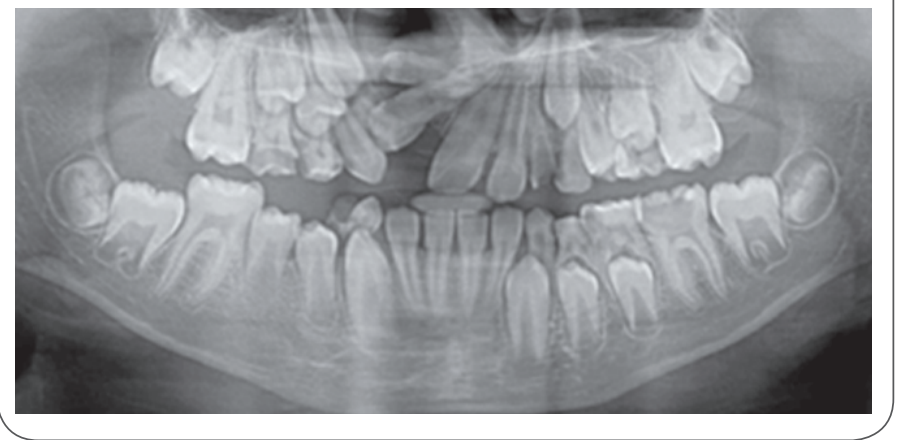

Figure 3: Intraoral aspect. The presence of misplaced tooth 11 is observed.

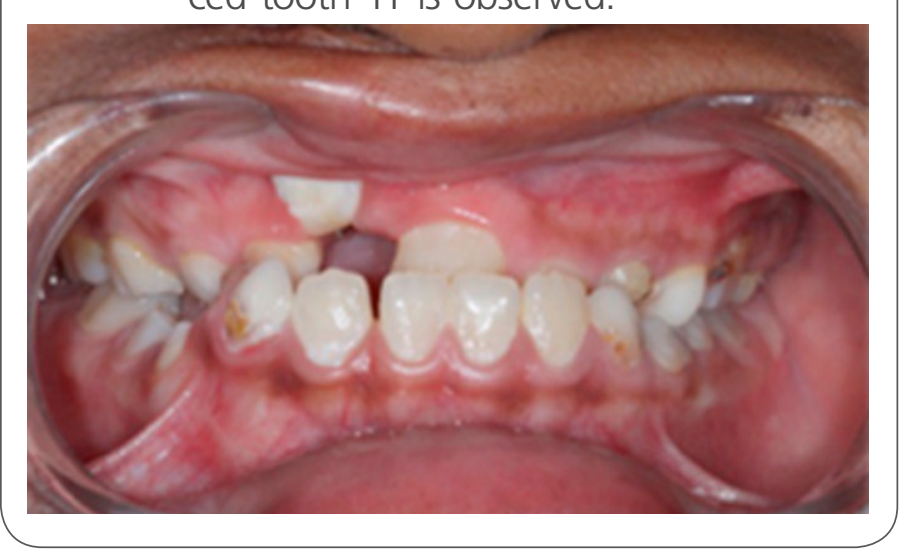


Based on the clinical findings, there was the proposal for performance of surgical approach for tooth removal through transnasal access, under general anesthesia and tracheal intubation. Through a technique called exodontia with the use of extractors and forceps (Figure 4), with subsequent closure of the mucosa of the nasal fossa floor (Figure 5) and of the alveolar mucosa through intraoral access still treating the oronasal fistula (Figure 6).

In follow-up, 30 days after surgery the patient is with satisfactory aesthetic-functional re-stabilization. Currently with good evolution, under orthodontic treatment to include the tooth 11 in the maxillary arch (Figure 7).

Figure 4: Transnasal access with apprehension and removal of the tooth with forceps 65.
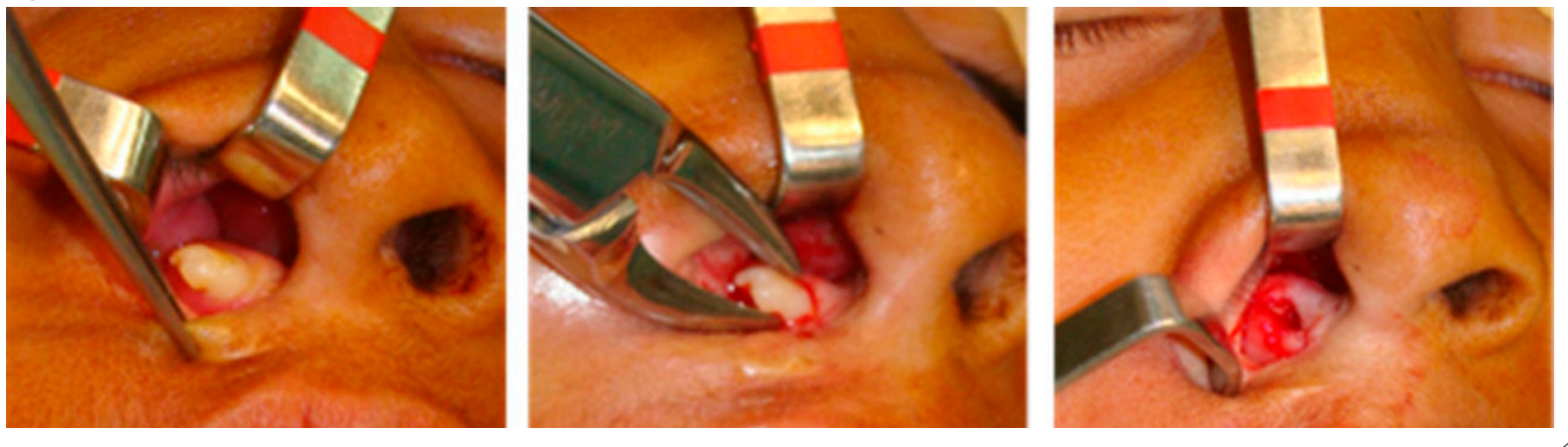

Figure 5: Intraoral access for closure of the nasal mucosa.

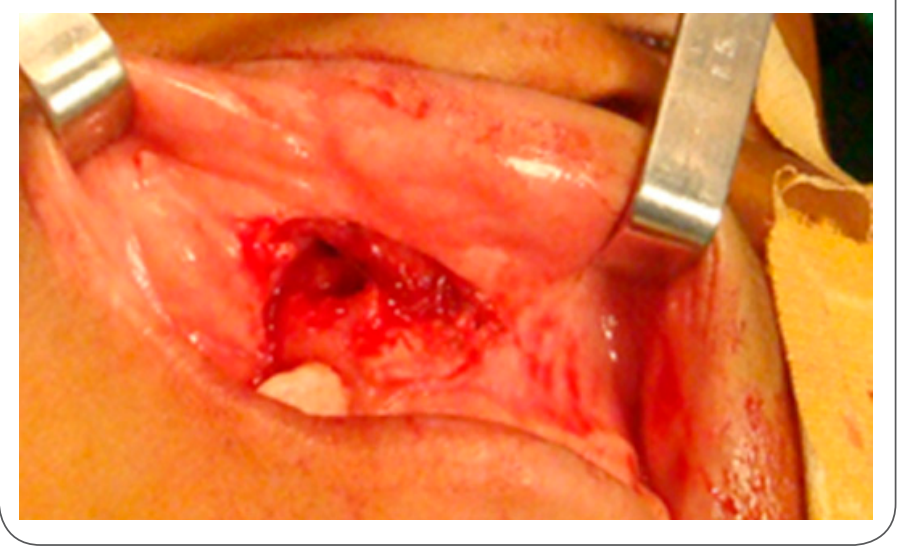

Figure 6: Suture of the nasal and oral mucosa promoting the closure of the oronasal fissure.
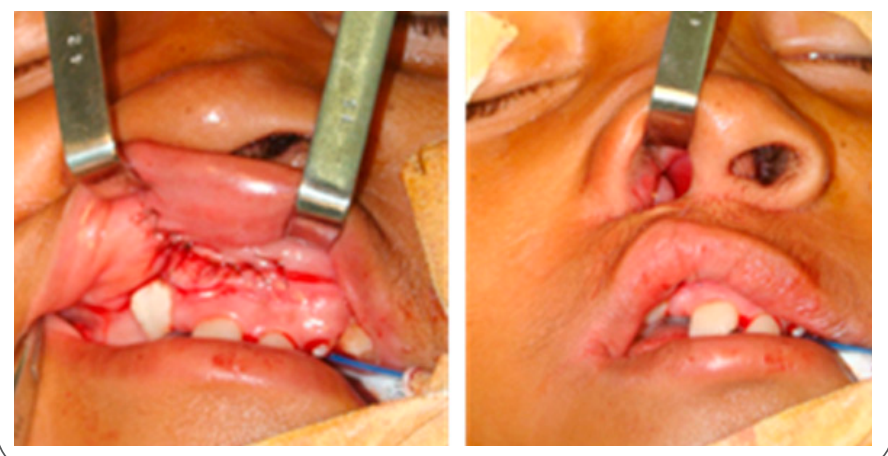

Figure 7: Clinical aspect in post-operative of 30 days.

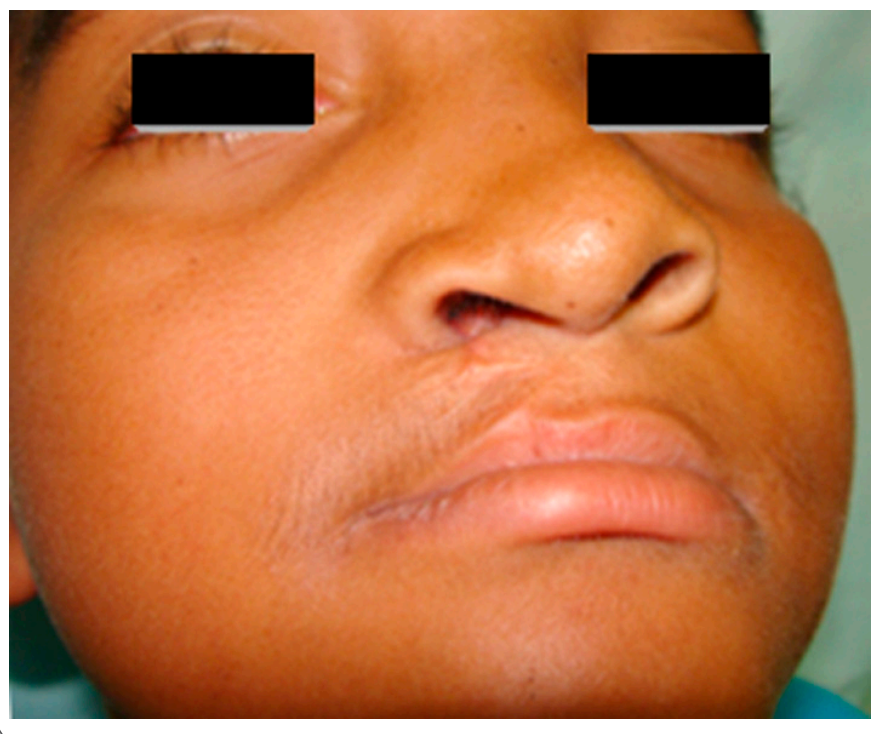




\section{Discussion}

The etiology of ectopic teeth is not made clear. Many theories have been proposed including palatine fissure, developmental disorders, displacement by trauma, cysts, infections, obstructions [KIM, et al., 2003]. This comes into agreement with the case in question which has as etiological factor a palatine fissure.

Commonly, they are displayed on the palate and maxillary sinus and are rarely found in the coronoid process, orbits, condyle and nasal cavity [I-HUNG LIN, et al., 2004; CASTILHO, et al., 2004].

Clinically, the intranasal tooth presents itself as a hard white mass located in the nasal cavity and surrounded by granulation tissue. It could be detected by means of panoramic, occlusion or face lateral radiography [CATILHO, et al., 2004].

The differential diagnosis of nasal ectopic teeth include foreign bodies, rhinoliths, granulomatous infections, bone sequestration, neoplasms and osteoma [Chao Yu, et al., 2015; Dhaferrerl, et al, 2014; Ozturk, et al., 2007]. Nasal endoscopy, panoramic, occlusal or lateral radiography assist in the diagnosis and treatment plan [WURTELE, et al., 1994]

The characteristic signs of the intranasal tooth are nasal obstruction, epistaxis, headache, epiphora, localized pain, presence of constant runny nose like a common cold, but that in some cases is accompanied by fetid odor [SeNKAL, et al., 2006].

Intranasal supernumerary teeth must be removed or looked after immediately after they are detected because of their morbidity potential [LEE, et al., 2006; IWAl, et al., 2012; KIM, et al., 2003]. However, in children with the roots of the permanent teeth fully formed, the removal is indicated to minimize the risk of development of injury of the dental follicle [LIN, et al., 2004].

The treatment consists on extraction of the ectopic tooth through transnasal, transpalatal or endoscopic access [LEE, et al., 2001]. However if the tooth is associated with osteomyelitis, intraoral fistula, or deviated septum, other approaches are indicated, including debridement and septoplasty [Sanel-Moghaddam, et al., 2009, Punde, et al., 2014]. The surgical removal through transnasal access has the advantage of avoiding large accesses, ostectomies and scraps that result in increased morbidity.

The use of transnasal access to approach the jaws have been described, and in this case of removal of ectopic tooth which constitutes an effective treatment, as long as the oral and maxillofacial surgeons have knowledge of anatomy and physiology of the face as well as the knowledge of the principles of the surgical technique. The most important is the fact that they possess "common sense" when they are using it [PITA-NETO, et al., 2015].

\section{Conclusion}

Supernumerary teeth in cleft patients can take ectopic positions and when their removal is indicated we should proceed with all available resources and more unexpected access routes.

\section{References}

- Reis, LFG.; Giovanini, A.; Namba, EL.; Silva, ELFM.; Garcia, MA. Supernumerary teeth in the orthodontic treatment. Revista SulBrasileira de Odontologia, 2006.; v. 3, p. 20-25

- Silva, LMC.; Miranda, SL.; Moreno, R.; Abrahão, M.; Luz, BHA. Endoscopically assisted removal of ectopic tooth in the nasal cavity: Case report. Res Bras Cir Craniomaxilofac, 2012; v. 15(3), p. 141-3.

- Gupta, YK.; Shah, N. Intranasal tooth as a complication of cleft lip and alveolus in a four years old child: Case report and literature review. Int J Paediatr Dent, 2001; v. 11(3), p. 221-4.

- Erkmen, N.; Olmez, S.; Onerci, M. Supernumerary tooth in the maxillary sinus: Case report. Australian Dental Jounal, 1998; v.43(3), p. 385-6.

- I-Hung Lin, MD.; Chung-Feng Hwang, MD.; Chih-Ying Su, MD.; Yi-Fen Kao, MD.; Jyh-Ping Peng, MD. Intranasal tooth: Report of Three Caso. Chang Gung Med, 2004; v. 27, p. 385-388.

- Castilho, ARF.; Pazin, DC.; Hussne, R.; Carrara, CFC. Dente intranasal em portador de fissura de lábio e palato: Relato de caso. $R$ Dental Press Ortodon Ortop Facial, 2004; v. 9, n. 6, p. 29-32. 
- Ferreira, AG.; Diefenbach, RS.; Heitz, C. Intranasal ectopic tooth in the patient with cleft lip and palate-Report of 2 Cases. $R$. Face. Odonto, 2004; v. 45, p. 38-40.

- Chao Yu, MD.; Deying Gu, BN.; Junnan An, MD.; Yurdi Tang, MD. Case presentation of an intranasal ectopic tooth in a pediaatric patient. American Journal Ofotolaryngolocy-Heard and Neck Medicine and Surgery, 2015; v. 36, p. 472-47.

- Kim, DH.; Kim, JM.; Chae, SW.; Hwang, SJ.; Lee, H.; Lee, HM. Endoscopic removal of an intranasal ectopic tooth. International Jounal of Pediatric Otorhinolaryngology, 2003; v. 67, p. 79-81.

- Dhafeeri, HOA.; Kavarodi, A.; Shaikl, KA.; Bukhari, A.; Hussain, OA.; Baramawy, AE. Recurrent epistaxis cause by an intranasal supernumerary tooth in a young adult. Am J Case Rep, 2014; v. 15, p. 291-293

- Ozturk, C.; Eryilmaz K, Cahur, B. Spernumerary tooth in the nose. Turkish Jounal of Medical Sciences, 2007; v. 37(4), p. 22730

- Wurtele, P.; Dufour, G. Radiology case of the month: A tooth in the nose. J Otolaryngol, 1994; v. 23, p. 67-68.

- Senkal, HA.; Suslu, AE.; Unal, OF. A rare cause of rhinolithiasis: Ectopic Tooth. Intenational Jornal of Pediatric Otorhinolaryngology Extra, 2006; v. 1, p. 249-252.

- Lee, JH. A nasal tooth associated with septal perforation: A rare occurrence. Euro Arch Otorhinolaryngol, 2006; v. 263(11), p. 1055-6.

- Sanei-Moghaddam, A.; Hyde, N.; Williamson, P. Endoscopic removal of a supernumerary tooth from the nasal cavity in an adult. British Jornal of Oral and Maxillofacial Surgery, 2009; v. 47, p. 484-485.

- Iwai, T.; Aoki, N.; Yamasbita, Y.; Omura, S.; Matsui, Y.; Maegawa, J.; Tobnai, I. Endoscopic removal of bolateral supernumerary intransal teeth. J Oral Maxillofac Surg, 2012; v. 70, p. 10301034.

- Lin, IH.; Hwang, CF.; Su, CY.; Kao, YF.; Peng, JP. Intranasal tooth: report of theree cases. Chang Gung Med J, 2004; v. 27(5), p. 385-9.

- Lee, FP. Endoscopic extraction of an intranasal tooth: a review of 13 Cases. Laryngoscope, 2001; v. 111(6), p. 1027-31.

- Punde, PA.; Patil, NM.; Pawar, RL. Unusal presentations of 'U-SHAPED' impacted maxillary cental incisor with intranasal root: Successful surgical Management. Ethiop J Health Sci, 2014; v. 24, p. $273-276$

- Pita-Neto, IC.; Franco, JMPL.; Santana, MDR.; Batista, HMT.; Soares, ECS.; Gondim, DGA.; Sandrini, FAL.; Abreu, LC.; Rodriques, LMR. Simplification on the Reduction of Cmminuted Mandibular Fractures for Stable Internal Fixation. Internation Archives of Medicine, 2015; v. (8), p. 1-9.

\section{Comment on this article:}

\section{(f) [in is $\mathbf{S}$ ?}

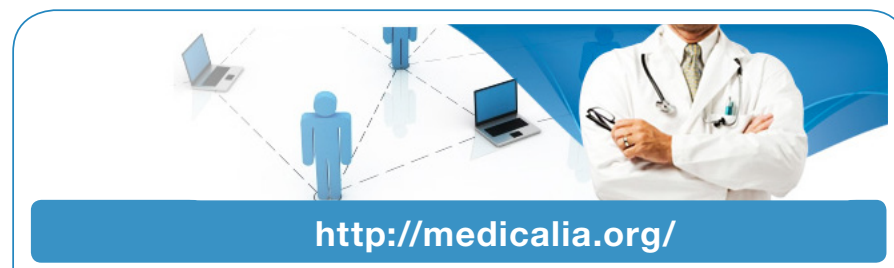

Where Doctors exchange clinical experiences, review their cases and share clinical knowledge. You can also access lots of medical publications for free. Join Now!

\section{Publish with iMedPub}

http://www.imed.pub

International Archives of Medicine is an open access journal publishing articles encompassing all aspects of medical science and clinical practice. IAM is considered a megajournal with independent sections on all areas of medicine. IAM is a really international journal with authors and board members from all around the world. The journal is widely indexed and classified Q1 in category Medicine. 